\title{
TEORI EKOKRITIK SASTRA: KAJIAN TERHADAP KEMUNCULAN PENDEKATAN EKOLOGI SASTRA YANG DIPELOPORI OLEH CHERYLL GLOTFELTY
}

Ecocriticism Theory: A Study of the Emergence of the Ecological Approach Proposed by Cheryll Glotfelty

\author{
Afriya Naili Zulfa \\ Program Studi Magister Kajian Sastra dan Budaya \\ Fakultas Imu Budaya, Universitas Airlangga \\ Address: Jl. Dharmawangsa Dalam Selatan, Kampus B, Surabaya, Indonesia 60286 \\ Surel: afriya.naili.zulfa-2016@fib.unair.ac.id
}

\begin{abstract}
Abstrak: Artikel yang berjudul Teori Ekokritik Sastra: Kajian terhadap Kemunculan Pendekatan Ekologi Sastra yang dipelopori Cheryll Glotfelty ini bertujuan untuk mengkaji dan membahas lebih lanjut mengenai latar belakang kemunculan teori ekokritik sastra juga definisi serta istilah-istilah kunci di dalamnya. Selain itu, artikel ini juga membahas lebih dalam mengenai inti pembahasan dan isu yang biasa diteliti dalam kajian yang menggunakan teori ekokritik sastra beserta cara penerapannya. Sebagai salah satu teori yang lumayan baru, teori ekokritik sastra mencakup topik dan isu yang sangat luas sehingga membuat kajian menjadi lebih fleksibel, meski demikian masih cukup jarang yang mengaplikasikan teori ekokritik sastra terutama dalam dunia kajian sastra di Indonesia. Maka dari itu, artikel ini mencoba untuk memberikan penjelasan singkat mengenai ekokritik sastra, pentingnya teori ekokritik sastra sehubungan dengan masalah lingkungan yang tengah dihadapi manusia, juga macam-macam cara penerapan yang diharapkan bisa membantu pembaca dan calon peneliti.
\end{abstract}

Kata Kunci: Alam, Budaya, Ekokritik sastra, Ekologi Sastra

\begin{abstract}
The article entitled Ecocriticism Theory: A Study of the Emergence of the Ecological Approach Proposed by Cheryl Glotfelty, aims to examine and discuss further about the background of the emergence of literary ecocritical theory as well as its definitions and all of the key terms in it. In addition, this article also discusses the core of the discussion and issues that are commonly examined in studies which use ecocriticism theory and how it is applied in literary study. As a considerably new theory, ecocriticism covers a wide range of topics and issues that make studies more flexible, however it is not so often used or applied as some other theories in the world of literary studies, especially in Indonesia. Therefore, this article tries to provide a brief explanation of ecocriticism and its definition, the importance of the literary ecocritical theory in relation to environmental problems faced by human beings nowadays, as well as the various ways of application that are expected to help and provide informations for the readers and prospective researchers.
\end{abstract}

Keywords: Nature, Culture, Ecocriticism, Ecological Approach 


\section{PENDAHULUAN}

Pada era pasca modernisme, studi sastra nampaknya berada pada tahap dimana adanya tuntutan untuk selalu melakukan revisi atau perubahan juga perluasan pada suatu teori yang sudah ada. Hal tersebut konstan terjadi pada hampir seluruh area dan cabang kajian sastra dengan beberapa tujuan, baik untuk mengembangkan, mengoreksi, atau bahkan untuk membuatnya menjadi lebih relevan dengan era saat ini.

Kajian sastra juga kerap megklaim bahwa upaya tersebut dilakukan dengan tujuan untuk menanggapi segala isu kontemporer yang muncul dan terjadi di dunia. Namun, hal ini seakan tidak berlaku pada salah satu isu yang menjadi masalah global yaitu krisis lingkungan hidup (Glotfelty 1996, xv). Banyak juga yang menganggap bahwa ahli sastra tidak memberikan rasa antusias yang sama pada isu tersebut sebelum munculnya studi mengenai sastra dan lingkungan serta kemunculan teori ekokritik sastra.

Pada era sekitar 70-80 an, muncul banyak gerakan-gerakan yang fokus pada isu ras, kelas, dan gender. Gerakan-gerakan tersebut terbukti dapat mempengaruhi dunia kajian sastra melihat banyaknya muncul studi berupa jurnal, buku, atau artikel mengenai isu tersebut. Namun berbeda dengan isu isu mengenai lingkungan hidup yang sepertinya tidak cukup menggugah peneliti untuk meneliti lebih lanjut mengenai isu-isu tersebut pada dunia kajian sastra (Glotfelty 1996, xvi).

Padahal jika diamati, beritaberita utama di koran atau surat kabar pada masa itu, terlihat jelas bahwa isu yang paling genting tidak jauh-jauh dari masalah lingkungan dan kerusakan alam. Beberapa contohnya, yaitu: peristiwa kebocoran minyak, pencemaran air, angka kepunahan spesies mahluk hidup yang makin meningkat, konflik dalam perebutan penggunaan lahan publik, pembuangan limbah nuklir, isu mengenai penipisan dan adanya lubang pada lapisan ozon, pemanasan global, serta hujan asam yang semakin sering terjadi karena tingginya tingkat polusi (Glotfelty 1996, xvi).

Maka dari itu, banyak yang mengkritik para pengkaji sastra yang dinilai terlalu akademis hingga melupakan masalah yang paling membutuhkan solusi pada saat itu dan kenyataan bahwa bumi tempat tinggal mereka juga sedang dilanda krisis. Hal ini yang kemudian memunculkan ketertarikan untuk mengembangkan pendekatan ekologi terhadap karya sastra dengan harapan untuk mengedukasi baik peneliti, penulis karya sastra, maupun pembaca mengenai isu-isu penting seputar masalah lingkungan, serta untuk menemukan dan mereformasi cara pandang manusia terhadap hubungan antara manusia dengan alam sendiri demi harapan untuk mencapai 
hubungan yang harmonis antara keduanya.

Pendekatan ekologi

terhadap karya sastra, maka dari itu muncul karena adanya kekhawatiran mengenai masalah lingkungan yang sedang terjadi dan kondisi relasi antara manusia dengan alam pada saat itu yang cenderung menempatkan manusia sebagai yang mendominasi dan alam sebagai yang didominasi. Pandangan atau pendekatan ini juga muncul karena adanya kesenjangan atau pemisahan mutlak antara isu lingkungan yang terjadi di depan mata dengan dunia kajian sastra.

Selain itu, isu-isu mengenai lingkungan serta tema-tema yang mengacu pada glorifikasi terhadap alam juga banyak menginspirasi para penulis yang menjadi terpacu untuk memasukkan aspek-aspek yang berhubungan dengan isu lingkungan hidup pada karya sastra mereka. Maka dari itu, tidak ada alasan untuk membatasi ahli sastra dalam menganalisa lebih lanjut mengenai isu tersebut.

Meskipun dinilai jarang, jika ditelusuri lebih lanjut nyatanya upaya dalam kajian sastra untuk mengaplikasikan pendekatan ekologi telah dilakukan sejak tahun 70-an (Glotfelty 1996, xvi). Namun, karena studi-studi tersebut belum memiliki payung teori yang menaungi beberapa topik yang dibahas, menyebabkan kajiankajian tersebut kemudian dikelompokkan pada cabang teori yang sudah ada. Hal tersebut yang membuat studi-studi tersebut terkesan diabaikan. Selain itu, penelitian yang dilakukan terkesan terisolasi karena jarang adanya dialog antar satu peneliti dengan peneliti lainnya karena ketidaktahuan atas eksitensi masing-masing (Glotfelty 1996, xvii).

Baru pada pertengahan tahun 80-an, ketika para ahli kritik sastra mulai bekerjasama dan menghubungkan antara satu penelitian dengan penelitian lainnya, ekokritik sastra makin berkembang dan mulai meraih popularitas pada awal tahun 90-an (Glotfelty 1996, xvii).

Perkembangan pesat ekokritik sastra pada dunia kajian sastra ditandai oleh beberapa peristiwa. Pada tahun 1985, Frederick 0. wage sebagai editor dari Teaching Environmental Literature: Materials, Methods, Resources memuat setidaknya sembilan belas peneliti yang berbeda dengan tujuan untuk meningkatkan kesadaran akan masalah lingkungan pada dunia sastra. Alicia Nitecki kemudian membangun The American Nature Writing Newsletter pada tahun 1989, sebagai wadah untuk menerbitkan esai, review buku, jurnal, serta segala informasi yang berhubungan dengan kajian pada tulisan-tulisan atau karya sastra yang mengusung alam sebagai tema atau topik nya (Glotfelty 1996, xvii-xviii).

Hal tersebut kemudian mengarah pada semakin populernya teori ekokritik sastra pada tahun 1990 (Selden, Widdowson and Brooker 
$2017,262)$. Salah satu tokoh penting yang sekaligus dinobatkan sebagai pelopor dari teori ini yaitu Cheryll Glotfelty dengan esai nya yang berjudul, The Ecocriticism Reader: Landmarks in Literary Ecology (1996). Menurut Harold Fromm sebagai editor dari antologi dengan judul yang sama, pengembangkan pendekatan ekologi sastra serta kemunculan teori ekokritik diawali dengan ambisi Glotfelty untuk menemukan hubungan antara karya sastra dengan lingkungan sekitar. Glotfelty memiliki ketertarikan pada bidang ekologi namun di sisi lain juga ingin mempertahankan identitas-nya sebagai seorang ahli dalam bidang sastra. Tujuan utama Cheryll Glotfelty pada saat itu yaitu untuk menyebarluaskan konsep mengenai ekokritik sastra, menerbitkan antologi yang berisi kumpulan beberapa esai mengenai ekokritik, sekaligus menjadi profesor asal Amerika pertama dalam bidang sastra dan lingkungan hidup (Glotfelty 1996, ix-x).

Kajian terhadap sastra dan lingkungan hidup meliputi beragam topik dan cabang, seperti; pendekatan ekologi, environmentalisme, konsep alam dan penggambarannya pada karya sastra, relasi antara manusia, mahluk hidup lainnya, serta alam, juga isu mengenai dikotomi antara alam dan budaya atau manusia (Glotfelty 1996, xviii). Melihat isu dan topik yang sangat beragam, teori ekokritik sastra dinilai sangat luas dan selalu terbuka untuk penambahan teori atau konsep yang baru. Hal tersebut kemudian memunculkan pertanyaan mengenai apa sebenarnya definisi dari teori ekokritik sastra, istilah-istilah kunci yang ada di dalamnya, serta cara penerapannya pada suatu karya sastra.

\section{METODE}

Metode yang digunakan untuk artikel ini yaitu studi pustaka, dikarenakan fokus pada artikel ini yang hendak mengkaji sebuah teori yaitu teori ekokritik sastra. Kajian ini akan memanfaatkan beberapa sumber baik berupa buku, jurnal, atau artikel yang terkait mengenai teori ekokritik sastra untuk mendapatkan data-data lengkap mengenai teori tersebut. Sumber-sumber tersebut kemudian digunakan untuk mengungkap definisi, istilah-istilah kunci, cara penerapan, juga cabang-cabang dari teori ekokritik itu sendiri. Selain itu, artikel ini juga menerapkan metode deskriptifanalisis yang meliputi penentuan objek yaitu teori ekokritik sastra, pengumpulan data seperti yang sudah disebutkan di atas, dan yang terakhir yaitu analisis yang berisi penjelasan lebih lanjut mengenai teori ekokritik sastra.

\section{HASIL DAN PEMBAHASAN}

Pada bagian ini, penulis akan menjelaskan lebih lanjut mengenai definisi teori ekokritik sastra, aspekaspek penting di dalamnya, serta penerapannya dalam kajian sastra.

\section{Definisi Ekokritik Sastra}

Istilah 'Ecocritic' sebenarnya berasal dari gabungan antara dua kata dalam bahasa yunani, yaitu: oikos dan kritos. Oikos memiliki arti house (rumah), sedangkan kritos memiliki 
arti judge (juri atau kritikus) (Howarth 1996, 69). Dari arti harfiah tersebut bisa diambil makna ekokritik sebagai individu atau pandangan yang menilai karakteristik dari suatu tulisan yang menggambarkan tentang efek budaya terhadap alam. Menurut Edward Hoagland, Oikos dalam ekokritik sastra dapat diartikan sebagai rumah terluas tempat mahluk hidup berada yaitu bumi ini. Sedangkan, kritos adalah yang mengawasi agar rumah tersebut beserta seisinya tetap terjaga dan teratur (Howarth 1996, 69).

Istilah ekokritik sastra sendiri pertama kali digunakan oleh William H. Rueckert pada tahun 1970-an dalam esai nya yang berjudul, Literature and Ecology: An Experiment in Ecocriticism (1978). Konsep yang diungkapkan oleh Rueckert cenderung memperlakukan suatu teks sebagai suatu ekosistem, kajiannya juga terfokus pada adanya kesatuan antara teks tersebut dengan manusia (Rueckert 1996, 68). Selain itu, konsep ekokritik yang diusung Rueckert juga hanya fokus pada aspek sains pada ekologi yang membuatnya dianggap terlalu terbatas atau restriktif (Glotfelty 1996, xx). Hal tersebut berbeda dengan apa yang disebut ekokritik saat ini, yaitu teori yang mengungkapkan segala hubungan yang mungkin muncul antara karya sastra dan lingkungan fisiknya (Glotfelty 1996, xx).
Ekokritik sastra kemudian berevolusi menjadi bidang kajian sastra yang memiliki banyak cabang dan makna yang semakin luas. Salah satu tokoh yang dianggap paling berjasa dalam pengembangan teori tersebut yaitu Cheryll Glotfelty. Ia mendefinisikan ekokritik sastra sebagai teori atau kritik yang mengkaji mengenai hubungan antara karya sastra dan lingkungan fisiknya (Glotfelty 1996, xviii). Glotfelty juga menyebut teori ekokritik sastra sebagai pendekatan yang fokusnya ada pada bumi juga lingkungan sekitar (Glotfelty 1996, xviii).

Teori kritik sastra kebanyakan fokus pada hubungan antara penulis, teks, dan dunia luar. Dunia luar dalam hal ini memiliki arti yang sempit, yaitu sebagai lingkungan sosial, lingkungan dimana penulis berasal atau setting tempat pada suatu teks. Sedangkan, teori ekokritik sastra mencoba untuk memperluas makna dari dunia tersebut dengan cara meliputi keseluruhan ekosfer atau ekosistem yang ada di bumi ini (Glotfelty 1996, xix).

Secara sederhana, teori ekokritik sastra dapat diartikan sebagai teori yang mengkaji relasi antara mahluk hidup dan alam, dalam penerapannya pun ekokritik sastra biasanya fokus pada bagaimana alam digambarkan pada suatu karya sastra. Tujuan dari ekokritik sastra sendiri yaitu untuk mengubah cara pandang atau ideologi dengan memanfaatkan ilmu yang berasal dari bidang lain yang sudah ada sebelumnya, khususnya 
sains dalam mendukung proses pembacaan pada suatu karya sastra (Howarth 1996, 78).

Ada beberapa alternatif istilah dalam menyebut teori tersebut selain ekokritik sastra, seperti: ecopoetics, environmental literary criticism dan green studies. Namun, ekokritik sastra dipilih karena dinilai singkat dan cukup efisien untuk mencakup segala topik yang dibahas di bawah payung teori tersebut. Para ahli sastra juga lebih memilih istilah eco-daripada envirokarena istilah enviro dianggap terlalu antroposentris, dimana segalanya berpusat pada manusia yang dikelilingi oleh sesuatu yang berbeda dari mereka, yaitu lingkungan atau alam itu sendiri. Sedangkan istilah eco- menyaratkan adanya ketergantungan, integrasi, dan keterkaitan yang erat antara aspek-aspek yang ada di dalam lingkungan dan kehidupan (Glotfelty 1996, ix-x).

Meskipun memiliki banyak cabang dan mencakup fokus dan topik yang beragam. Nilai dasar dari teori ekokritik sastra yaitu kenyataan bahwa budaya atau manusia memiliki ikatan erat dengan lingkungan sekitar mereka. Baik manusia juga alam, keduanya saling mempengaruhi dan bergantung pada satu sama lain. Teori ekokritik sastra juga menekankan pada adanya interkonektivitas antara alam dan budaya yang juga meliputi bahasa dan sastra (Glotfelty 1996, xix).
Dalam teori ekokritik sastra sendiri terdapat empat disiplin, yaitu: ekologi, etika atau tata susila, bahasa, serta kritik (Howarth 1996, 71). Ekologi menjelaskan tentang adanya hubungan atau keterkaitan antara alam dan budaya. Etika atau tata susila merupakan cara untuk mengatasi suatu konflik sosial. Bahasa sendiri dalam hal ini mengacu pada bagaimana kata atau ungkapan mencerminkan kehidupan manusia, mahluk hidup lainnya, serta lingkungan alam sekitar mereka. Sedangkan yang terakhir yaitu, kritik merupakan tahap penilaian kualitas dan integritas suatu karya yang mengusung tema atau topik mengenai lingkungan (Howarth 1996, 71).

\section{Gelombang Pertama dan Kedua Teori Ekokritik Sastra}

Seperti teori-teori kritik sastra lainnya, teori ekokritik sastra juga melewati fase-fase perubahan, baik pada fokus atau penerapannya. Teori ekokritik sastra pada gelombang pertama cenderung lebih fokus pada tulisan-tulisan mengenai alam dan teks dengan tema yang ekosentris. Tujuan utama pada teori ekokritik sastra di gelombang pertama yaitu tercapainya selebrasi alam. Teori ekokritik sastra pada gelombang pertama juga cenderung benar-benar mengutamakan alam di atas lainnya. Hal ini namun dapat mengarah pada gerakan anti humanisme yang bukannya menyelesaikan isu-isu lingkungan yang ada namun malah akan menciptakan masalah baru. 
Maka dari itu, pada gelombang kedua, teori ekokritik sastra juga membahas adanya rasisme dalam lingkungan hidup, dimana manusia cenderung terlalu mendominasi alam yang ditempatinya atau mahluk hidup lainnya (Goodbody 2007, 13). Teori ekokritik sastra pada gelombang kedua juga cenderung fokus pada pandangan holistik yang memungkinkan peneliti untuk melihat suatu masalah secara keseluruhan dan menemukan solusi yang efektif dengan membenarkan adanya keterkaitan antara segala aspek yang ada di dunia ini, begitu pula dengan masalah lingkungan yang terjadi. Masalah-masalah tersebut tidak bisa sepenuhya diselesaikan dengan fokus pada satu masalah saja, namun dengan menemukan akar atau penyebab utama dari masalah-masalah tersebut. Manusia juga harus memastikan bahwa dalam penyelesaian satu masalah hendaknya tidak malah memperburuk masalah lainnya.

Selain itu, banyak kajian yang dilakukan pada era gelombang kedua teori ekokritik sastra yang fokus pada hubungan timbal balik atau interkonektivitas antara manusia dan alam, dengan tujuan utama untuk menemukan cara bagaimana agar manusia dapat hidup berdampingan secara harmonis dengan alam dan mahluk hidup lainnya, serta merubah cara pandang manusia yang cenderung ingin mendominasi alam dan terusmenerus mengeksploitasi-nya.

Perbedaan antara teori ekokritik sastra pada gelombang pertama dan kedua juga dapat dilihat dari bagaimana keduanya memaknai apa yang disebut sebagai lingkungan (Howarth 1996, 69). Pada gelombang pertama, lingkungan hanya terbatas pada lingkungan alami saja, sedangkan teori ekokritik sastra gelombang kedua juga menaruh perhatian pada lingkungan yang ditempati manusia juga jejak-jejak alam di kehidupan kota. Selain itu, pada gelombang kedua, teori ekokritik fokus dalam menjaga lingkungan alam melalui aksi politik (Goodbody 2007, 12-13).

Seperti yang disebutkan sebelumnya mengenai bagaimana teori ekokritik sastra gelombang pertama dan kedua memandang relasi antara manusia dan alam, teori ekokritik sastra pada gelombang pertama dinilai lebih realistis dan ideal karena mempertimbangkan segala macam hubungan antara alam dan manusia, baik yang menguntungkan atau merugikan. Poin terpenting lainnya yaitu kenyataan bahwa pada gelombang kedua, mulai tumbunya kesadaran bahwa sejatinya manusia dan alam memiliki keterkaitan yang erat dan saling mempengaruhi satu sama lain, tidak seperti pada gelombang pertama yang menganggap bahwa dalam menyelesaikan masalah alam hanya dapat dicapai melalui proses eliminasi aspek budaya yang dalam hal ini juga meliputi manusia itu 
sendiri yang dianggap sebagai sumber dari masalah alam tersebut.

\section{Nature vs Culture}

Meskipun istilah alam (nature) dan budaya (culture) sering dimaknai sebagai dua hal yang seakan terpisah dan sangat berbeda satu sama lain, namun kenyataannya kedua istilah tersebut memiliki kaitan yang sangat erat. Maka dari itu, teori ekokritik sastra fokus pada bagaimana kita memaknai kedua istilah tersebut dan juga menentang adanya dikotomi antara alam dan budaya. Teori ekokritik sastra juga mencoba untuk menggusur dogma yang menyatakan bahwa budaya adalah yang berhak menguasai dan memiliki dan memanfaatkan alam yang seringkali justru menimbulkan kerusakan di bumi ini (Howarth 1996, 77).

Teori ekokritik sastra tidak mencoba untuk membuktikan bahwa alam lebih baik dari manusia ataupun sebaliknya, melainkan untuk menunjukkan bahwa keduanya saling terkait, saling mempengaruhi, dan memiliki hubungan timbal balik yang kuat. Maka dari itu, penempatan keduanya pada suatu hirarki justru tidak sejalan dengan apa yang hendak dicapai pada teori tersebut. Dalam ekokritik sastra sendiri, alam memang dianggap sebagai sesuatu yang ada di luar diri kita sebagai manusia, namun tidak bisa dipungkiri bahwa alam memiliki pengaruh besar dalam kehidupan kita.

Dalam teori ekokritik sastra sendiri pun terkadang pemaknaan alam dan budaya dapat dianggap problematik, karena jika terjadi glorifikasi yang berlebihan pada alam maka akan mengarah pada pandangan anti-humanisme. Sedangkan jika terlalu fokus pada sisi manusia dan bagaimana mereka memandang serta memperlakukan alam malah bisa menuju pada paham yang antroposentris. Maka dari itu, perlu ditemukan keseimbangan dalam menerapkan teori ekokritik sastra untuk mencapai koeksistensi yang harmonis pula antara seluruh mahluk hidup dan alam tempat mereka tinggal.

Karena hal tersebut, istilah nature dan culture dianggap Raymond William sebagai dua kata yang paling rumit untuk dimaknai dalam bahasa inggris (Williams 1983, 219). Dalam ekokritik sastra ada beberapa hal yang perlu diperhatikan dalam memaknai alam itu sendiri, seperti: apakah mungkin untuk menghasilkan makna yang obyektif tentang alam, apakah perlu menemukan makna yang obyektif, bagaimana cara hidup berdampingan dengan alam, apa yang dimaksud dengan hubungan harmonis dengan alam, apakah manusia termasuk bagian dari alam, dan jika manusia mulai ikut campur dalam keberlangsungan alam, apakah hal tersebut berarti keadaan alami dari alam itu sendiri sudah tercemar (Van Wyk 2012, 1).

Dalam proses pemaknaan alam sendiri juga membuktikan adanya 
kaitan erat antara alam dan budaya, karena sejatinya proses pemaknaan tidak terlepas dari pengaruh budaya. Harus diakui juga bahwa makna dari alam selalu bergantung pada budaya dan bagaimana budaya itu sendiri memaknai alam (Van Wyk 2012, 2). Namun sayangnya, dalam proses pemaknaan yang terjadi dengan adanya pengaruh budaya harus melibatkan penempatan kedua istilah tersebut pada posisi yang menunjukkan hirarki atau superioritas salah satu di antaranya. Karena budaya juga dianggap mewakili manusia maka proses pemaknaan tersebut menghasilkan makna dari alam yang berada di posisi lebih rendah dari manusia dan sesuatu yang benar-benar terpisah juga berbeda dari manusia.

Seiring berjalannya waktu, dapat dilihat adanya pergeseran makna dari kata alam. Alam pernah memiliki makna yang meliputi segalanya yang ada di dunia ini, yang kemudian bergeser menjadi segalanya yang belum tersentuh oleh manusia menurut Karl Marx (Soper 2000, 18). Namun, pengertian tersebut sepertinya kini perlu dipertanyakan karena kenyataan bahwa area yang belum tersentuh oleh manusia kini tinggal sangat sedikit. Sedangkan, Raymond William memaknai alam secara general namun masih cukup memiliki batas yang jelas. Alam menurut William yaitu segalanya yang tidak diciptakan oleh manusia, atau jika memang diciptakan atau tidak sengaja tercipta karena campur tangan manusia harus merupakan sesuatu yang ada sejak kurun waktu yang sangat lama, seperti: pagar pohon atau gurun (Williams 1983, 223).

Adanya makna dari alam tidak terlepas dari eksistensi makna budaya yang seringkali dianggap sebagai kebalikan atau lawan dari kata alam tersebut. Namun, hal ini seringkali menyebabkan budaya ditempatkan pada posisi yang lebih atas atau lebih diprioritaskan dibanding dengan alam (Selden, Widdowson and Brooker 2017, 264). Budaya sendiri dapat didefinisikan sebagai seperangkat norma, kepercayaan, nilai, dan gagasan yang ada di dalam suatu kelompok sosial (Walsham 2002, 361). Dalam teori ekokritik sastra sendiri, budaya biasanya digambarkan untuk mewakili manusia dan apa-apa saja yang diciptakannya. Namun di lain sisi, ekokritik sastra juga harus mencegah adanya anggapan bahwa istilah budaya merujuk sepenuhnya pada budaya manusia saja karena lagi-lagi hal ini akan mengarah pada disrepansi antara manusia dan mahluk hidup lainnya karena hanya memfokuskan pada budaya manusia saja (Selden, Widdowson and Brooker 2017, 264).

\section{Ciri Karya Sastra yang Menjadi Objek Kajian Teori Ekokritik}

Dalam melakukan suatu kajian, hal yang pertama dilakukan tentu saja menentukan objek yang hendak dikaji atau diteliti. Begitu pula dalam teori ekokritik sastra, perlu adanya 
beberapa ciri atau karakteristik pada karya sastra yang harus diperhatikan oleh peneliti sebelum memutuskan untuk menerapkan teori ekokritik sastra pada karya tersebut.

Salah satu ciri paling umum yaitu penggambaran alam sebagai aspek penting dalam suatu karya, penggunaan isu mengenai alam sebagai tema atau topik dalam karya tersebut. Selain itu, dalam karya yang bisa dikaji melalui teori ekokritik biasanya tempat atau setting berperan besar dalam jalan cerita pada suatu karya. Hal ini terjadi karena dalam ekokritik sastra tidak hanya fokus pada hubungan antara manusia dengan mahluk hidup lainnya, melainkan juga hubungan mereka dengan tempat atau lingkungan sekitar.

Dalam sudut pandang ekokritik sastra, tempat juga dapat didefinisikan sebagai lingkungan dimana nilai-nilai yang dianut manusia telah ditetapkan, sehingga memiliki keterkaitan yang kuat dan biasanya dimaknai sesuai dengan hubungan mereka dan budaya manusia (Larsen 2007, 349). Maka dari itu, manusia cenderung memiliki ikatan batin kuat dengan suatu tempat tertentu, dan lagi-lagi menunjukkan adanya hubungan erat antara budaya dan alam dimana manusia sebagai yang bisa merasakan ikatan tersebut lah yang juga dapat mendefinisikan arti dari tempat tersebut. Meskipun demikian, perlu diingat bahwa manusia tetap sangat bergantung pada lingkungan alami di sekitar mereka dalam mendefinisikan alam itu sendiri.

Selain beberapa hal yang sudah disebutkan di atas, Lawrence Buell lebih spesifik menyebutkan empat karakteristik utama teks dengan tema lingkungan, antara lain, yaitu: lingkungan atau tempat hadir dalam suatu karya sastra tidak hanya sebagai setting semata saja melainkan memiliki peran penting di dalamnya, kepentingan manusia bukan satusatunya kepentingan yang sah atau mutlak, lingkungan digambarkan sebagai sebuah proses, dan yang terakhir yaitu akuntabilitas manusia terhadap lingkungan adalah bagian dari orientasi etis dalam teks (Buell 2005, 7-8)

Dengan memperhatikan ciri dan karakteristik tersebut terlebih dahulu, calon peneliti dapat terhindar dari pemaksaan penerapan teori ekokritik pada karya yang ternyata tidak sesuai dengan apa yang perlu dikaji atau dibahas dalam ekokritik sastra. 


\section{Cara Penerapan Teori}

Dalam pengaplikasiannya yang paling umum, teori ekokritik sastra fokus pada tiga pertanyaan, yaitu: bagaimana alam direpresentasikan dalam suatu karya sastra, apakah ada perbedaan antara penggambaran alam di dalam karya sastra dengan alam yang asli, dan yang terakhir yaitu apa ideologi dibalik representasi alam tersebut.

Beberapa pertanyaan lain dan topik atau fokus yang sering diajukan dan diteliti dalam kajian teori ekokritik sastra (Glotfelty 1996, xix), yaitu:

1. Apa peran dari alam atau setting tempat dalam suatu karya?

2. Apakah adanya aspek alam dalam suatu karya mencerminkan adanya nilainilai ekologis?

3. Bagaimana penggambaran kita sebagai manusia mengenai alam dapat mempengaruhi cara kita memperlakukan alam itu sendiri?

4. Bagaimana

mengkategorikan suatu karya sastra dengan tema tentang lingkungan sebagai suatu genre?

5. Apakah ada perbedaan antara bagaimana laki-laki dan perempuan menulis tentang alam?

6. Bagaimana literasi dapat mempengaruhi hubungan antar manusia dengan alam?

7. Perubahan konsep wilderness dari waktu ke waktu.
8. Pembuktian bahwa ilmu sains juga terbuka untuk dikaji dalam dunia sastra.

9. Bagaimana isu mengenai lingkungan mempengaruhi sastra dan budaya kontemporer?

Pengaplikasian teori ekokritik sastra sendiri cenderung fleksibel karena banyaknya konsep dan cabangcabang teori yang ada dalam naungan teori tersebut. Calon peneliti hanya perlu menemukan konsep atau cabang teori yang cocok dan pas untuk digunakan dalam mengkaji isu dan mencapai tujuan dari penelitian yang mereka lakukan.

\section{Antroposentrisme dan Ekosentrisme}

Dalam suatu kajian sastra yang menggunakan ekokritik sastra sebagai teori, di akhir analisa tentu harus disertai dengan pengungkapan ideologi yang ada pada suatu karya sastra tersebut. Ideologi yang biasanya ditemukan pada suatu karya yang dikaji dengan teori ekokritik sastra, yaitu: antroposentrisme dan ekosentrisme. Sebagai langkah terakhir dalam suatu kajian, biasanya peneliti diharuskan untuk menentukan apakah suatu karya sastra cenderung menjunjung tinggi ideologi antroposentrisme atau ekosentrisme.

Secara sederhana, pandangan antroposentrisme menempatkan manusia sebagai pusat dari segala hal, juga mementingkan kebutuhan dan keinginan manusia saja (Buell 2005, 134). Sedangkan, ekosentrisme yang merupakan kebalikannya adalah pandangan yang menganggap eksistensi seluruh entitas sama pentingnya dalam kehidupan di bumi 
ini, baik yang hidup maupun tidak, dan mengutamakan pentingnya untuk tidak merusak alam serta hidup berdampingan dengan alam (Buell 2005, 137).

Definisi dari kedua istilah ideologi yang saling berbanding terbalik tersebut juga diungkap oleh Lawrence Buell. Antroposentrisme menurut Buell yaitu suatu asumsi atau pandangan yang memprioritaskan atau mengutamakan kepentingan dan keinginan manusia dibanding dengan kepentingan dan keinginan mahluk lain dan alam sekitarnya (Buell 2005, 134). Sedangkan, ekosentrisme merupakan pandangan yang menilai bahwa seluruh organisme termasuk manusia adalah bagian dari suatu jaringan atau komunitas biotik yang lebih besar dari dirinya yang berfungsi untuk mengarahkan dan mengatur kepentingan serta keinginan manusia atas segala hal yang ada di bumi, terutama alam (Buell 2005, 134). Ekosentrisme juga bisa didefinisikan sebagai pandangan mengenai lingkungan yang menghargai dan memberi perhatian penuh terhadap kepentingan serta kebutuhan dari keseluruhan ekosfer dibanding dengan kepentingan masing-masing spesies (Buell 2005, 137).

Jika dilihat sekilas saja maka dapat disimpulkan bahwa teori ekokritik sastra cenderung mengutamakan ekosentrisme. Hal tersebut terjadi karena antroposentrisme dinilai sebagai sumber terjadinya masalahmasalah lingkungan, karena penempatan kepentingan dan keinginan manusia di atas segalanya yang kemudian mengarah pada kecenderungan manusia untuk mengeksploitasi alam. Selain itu, antroposentrisme juga merupakan akar dari adanya dikotomi antara alam dan budaya yang benar benar ditentang dalam teori ekokritik sastra. Berbeda dengan ekosentrisme yang juga memperhatikan kepentingan mahluk lain dan lingkungan alam sekitar, yang memungkinkan manusia untuk melihat adanya ketergantungan antara dirinya dan alam dan mulai mempertimbangkan serta berusaha untuk mencari cara agar bisa hidup berdampingan secara harmonis dengan alam.

\section{SIMPULAN}

Melalui penjelasan dan paparan di atas, dapat disimpulkan bahwa teori ekokritik sastra mencoba untuk menjembatani antara ilmu sains dengan dunia sastra dimana para pelopornya ingin menunjukkan kontribusi yang bisa diberikan oleh kajian pada dunia sastra dalam menangani isu global yang dalam hal ini menyangkut akan isu lingkungan hidup dan kerusakan lingkungan atau alam.

Sebagai suatu teori, ekokritik sastra memang tidak langsung memberikan solusi konkrit seperti dalam ilmu sains dalam penyelesaian masalah lingkungan tersebut, namun ekokritik sastra fokus pada proses merubah pandangan manusia terhadap alam serta hubungan mereka dengan seluruh yang ada di bumi ini.

Eksistensi teori ekokritik sastra sendiri memungkinkan para peneliti untuk mengungkap hubungan antara manusia dan alam yang dapat ditemukan pada suatu karya sastra dan karena ekokritik sastra termasuk teori yang sangat luas dengan cabang- 
cabang teori dan konsep yang beragam, peneliti bisa lebih fleksibel dalam menentukan mana yang paling tepat untuk isu penelitian mereka, karena dalam teori ekokritik sastra tidak ada yang dianggap sebagai cara analisa paling mutlak seperti yang dapat ditemui pada teori-teori lain. Namun, di lain sisi karena terlalu luas, terkadang peneliti mungkin dihadapkan dengan kebingungan untuk memilih cabang konsep atau teori juga kesusahan untuk menghubungkan suatu cabang konsep atau teori dengan keseluruhan dari teori ekokritik sastra.

Terlepas dari hal itu, teori ekokritik sastra telah berjasa besar dalam memungkinkan adanya analisa mengenai representasi alam pada suatu karya sastra yang kemudian digunakan untuk menemukan cara berpikir yang tepat agar manusia bisa hidup berdampingan secara harmonis dengan alam.

\section{DAFTAR PUSTAKA}

Buell, Lawrence. 2005. The Future of Environmental Criticism: Environmental Crisis and Literary Imagination. Hoboken, New Jersey: Blackwell Publishing.

Glotfelty, Cheryll. 1996. The Ecocriticism Reader: Landmarks in Literary Ecology. Athens: The University of Georgia Press.

Goodbody, Axel. 2007. Nature, Technology and Cultural Change in Twentieth-Century German Literature: The
Challenge of Ecocriticism. New York: Palgrave Macmillan.

Howarth, William. 1996. "Some Principles of Ecocriticism." In The Ecocriticism Reader: Landmarks in Literary Ecology, by Cheryll Glotfelty and Harold Fromm, 69-91. Athens: The University of Georgia Press.

Larsen, Svend Erik. 2007. "To See Things for the First Time': Before and After Ecocriticism." Journal of Literary Studies, vol. 23, no. 4 341-73.

Rueckert, William. 1996. "Literature and Ecology: An Experiment in Ecocriticism." In The Ecocriticism Reader: Landmarks in Literary Ecology, by Cheryll Glotfelty and Harold Fromm, 105-123. Athens: University of Georgia Press.

Selden, Raman, Peter Widdowson, and Peter Brooker. 2017. A Reader's Guide to Contemporary Literary Theory Sixth Edition. Abingdon and New York: Routledge.

Soper, Kate. 2000. What is Nature? Culture, Politics and the NonHuman. Oxford: Blackwell.

Van Wyk, Karl. 2012. Different Natures: An Ecocritical Analysis of Selected Films by Terrence Malick, Werner Herzog and Sean Penn. Dissertation Johannesburg: University of the Witwatersrand.

Walsham, Geoff. 2002. "Cross-Cultural Software Production and Use: A Structurational Analysis ." MIS 
Afriya Naili Zulfa

Quarterly, Vol. 26, No. 4 359380.

Williams, Raymond. 1983.

Keywords: A Vocabulary of Culture and Society. London:

Croom Helm. 